\title{
Estimation of the daily water consumption by maize under Atlantic climatic conditions (A Coruña, NW Spain) using Frequency Domain Reflectometry - a case study
}

\author{
R. M. Mestas-Valero ${ }^{1}$, J. M. Mirás-Avalos ${ }^{1,2}$, and E. Vidal-Vázquez ${ }^{1}$ \\ ${ }^{1}$ Facultad de Ciencias. Universidade da Coruña-UDC, Campus A Zapateira s/n, 15008, A Coruña, Spain \\ ${ }^{2}$ current address: Estación de Viticultura y Enología de Galicia (EVEGA-INGACAL), Ponte San Clodio s/n, 32427, \\ Leiro-Ourense, Spain
}

Correspondence to: J. M. Mirás-Avalos (jmirasa@udc.es)

Received: 16 September 2011 - Revised: 12 December 2011 - Accepted: 23 January 2012 - Published: 23 March 2012

\begin{abstract}
Climatic variables and soil present a high spatiotemporal variability. Evapotranspiration estimations based on climatic variables may be inadequate for assessing soil water content in the root-influenced zone and/or soil water consumption by plants. Other methods may provide better estimates of this water consumption. The aim of this study was to quantify the soil moisture dynamics in the rootinfluenced zone and to assess the daily water consumption by the crop using Frequency Domain Reflectometry (FDR). The studied site is located in A Coruña (Spain). The study was carried out from June to October in 2008 and 2009, in a maize (Zea mays, L.) field on a silt-clay textured soil. Evapotranspiration was estimated by the Penman-Monteith equation using meteorological data from a station located on the experimental site. Soil water content in the root-influenced zone $(0-60 \mathrm{~cm}$ depth) was hourly monitored each $20 \mathrm{~cm}(0$ $20 \mathrm{~cm}, 20-40 \mathrm{~cm}$, and $40-60 \mathrm{~cm})$ using FDR. Evaluations were performed on days with slight or no rainfall. During the study period, the magnitude of the diurnal soil water loss was more evident in the first layer $(0-20 \mathrm{~cm}$ depth) and less important in the subsequent soil layers. The greatest consumption occurred between 14 and $19 \mathrm{~h}$, up to $53.64 \%$ of the total. Overall, daily water consumption increased significantly with soil water content ( $\mathrm{p}$-value $<0.001$ ). In general, water losses from the $0-20 \mathrm{~cm}$ soil layer were greater than in subsoil horizons due to maize water-uptake and evaporation. In contrast, water content in the deepest part of the soil profile was close to saturation, even on the driest days of the studied period. Evapotranspiration overestimate maize water requirements as its values were greater than those measured with the probe. In conclusion, FDR allows a more accurate estimation of the soil water balance. Therefore, monitoring
\end{abstract}

soil water content would be useful in the assessment of saturation risks or water stress (drought), thus aiding in the decision making, for instance, in irrigation management. Results from this study may help to improve irrigation practices in humid zones.

\section{Introduction}

Evapotranspiration is the combination of two different processes where water is lost from the soil surface and from the surface leaves by evaporation and from plants by transpiration. It constitutes one of the main components of the hydrological cycle and its estimation demands auxiliary meteorological data. The FAO Penman-Monteith method has recently been recommended as the sole standard method. It is a method with a strong likelihood of correctly predicting the potential evapotranspiration in a wide range of locations and climates (Aaron et al., 1996; Allen et al., 1998; D’Urso and Menenti, 1995).

Crop water requirements are affected by climatic parameters such as rainfall, wind speed or solar radiation. Hence, crop water requirements vary from year to year and so does water availability. On the one hand, some of these climatic variables are changing due to global warming (IPCC, 2007) and on the other hand, they present great spatial and temporal variability (e.g. Alsamamra et al., 2009; Mirás-Avalos et al., 2009). The latter reason has made them inadequate for indicating soil water consumption by plants, which is an essential parameter for assessing water availability. Thus, soil water content measurements are thought to be more useful in the assessment of crop water requirements (e.g. Vera

Published by Copernicus Publications on behalf of the European Geosciences Union. 
Table 1. Soil characteristics at the experimental site.

\begin{tabular}{|c|c|c|c|c|c|c|c|c|c|c|c|}
\hline \multirow{2}{*}{ Depth $(\mathrm{cm})$} & \multicolumn{3}{|c|}{ Texture analysis } & \multicolumn{5}{|c|}{ Chemical properties } & \multicolumn{3}{|c|}{ Physical properties } \\
\hline & $\begin{array}{c}\text { Sand } \\
(2-0.05 \mathrm{~mm}) \\
\%\end{array}$ & $\begin{array}{c}\text { Silt } \\
(0.05-0.002 \mathrm{~mm}) \\
\%\end{array}$ & $\begin{array}{c}\text { Clay } \\
(<0.002 \mathrm{~mm}) \\
\%\end{array}$ & $\begin{array}{c}\text { Organic } \\
\text { matter } \\
\%\end{array}$ & $\begin{array}{c}\text { Total } \\
\text { carbon } \\
\%\end{array}$ & $\begin{array}{c}\text { Total } \\
\text { nitrogen } \\
\%\end{array}$ & $\mathrm{C} / \mathrm{N}$ & $\mathrm{pH}$ & $\begin{array}{c}\text { Bulk } \\
\text { density } \\
\mathrm{g} \mathrm{cm}^{-3}\end{array}$ & $\begin{array}{c}\text { Field } \\
\text { capacity } \\
\%\end{array}$ & $\begin{array}{c}\text { Permanent } \\
\text { wilting point } \\
\%\end{array}$ \\
\hline $0-15$ & 24.85 & 54.75 & 20.38 & 7.49 & 3.27 & 0.25 & 10.18 & 5.38 & 1.28 & 31.16 & 13.04 \\
\hline $15-30$ & 24.78 & 54.90 & 20.35 & 7.02 & 2.99 & 0.21 & 10.60 & 5.84 & 1.28 & & \\
\hline $30-60$ & 27.05 & 53.93 & 19.08 & 2.96 & 0.70 & 0.07 & 9.51 & 5.44 & 1.29 & & \\
\hline $60-90$ & 31.13 & 54.78 & 14.05 & 2.25 & 0.26 & 0.05 & 5.46 & 5.31 & 1.32 & & \\
\hline
\end{tabular}

et al., 2009), even though soil properties also vary in time and space. Usually, irrigation is managed and supplied on the basis of water demands assessed by meteorological data (evapotranspiration); however, irrigation demand is not adequately met in certain regions (Cancela et al., 2006) since weather conditions are changing dramatically.

For instance, simulation experiments performed in the Duero Valley (Moratiel et al., 2011) predicted future increase in temperature, wind speed, and solar radiation, thus augmenting evapotranspiration. In other countries, increasing evapotranspiration rates have been observed from the 1980's till nowadays (Zhang et al., 2011).

In addition, the irregular, within-year rainfall distribution in the humid zone of Spain causes periods of soil water deficit, leading to a need for supplementary irrigation in the summer. Then, the variation of irrigation requirements is extremely high (Paz et al., 1996), making it impossible to predict the optimum irrigation schedule at the start of each growing season. In fact, predicted irrigation requirements for this region have varied considerably between years, ranging from 124 to $358 \mathrm{~mm}$ for silage maize (Cancela et al., 2006). Therefore, monitoring soil water content may be helpful to obtain a more accurate soil water balance (Vera et al., 2009). In the humid zone of Spain, the cost of water to the farmer is low, leading to inefficient usage (Neira and Paz, 1994). This produces an excess of water consumption for irrigation, which should be avoided in the context of changing climate and also because it implies environmental costs, particularly those due to leaching of fertilizers in subsurface runoff (Arauzo et al., 2003).

Several approaches have been proposed to ameliorate evapotranspiration estimations based mainly on satellite images (Papadavid et al., 2009) or soil water content monitoring (Goldhammer et al., 1999; Mounzer et al., 2008).

Indeed, soil water content in the vadose zone is one of the most important variables for the continuum soil-plantatmosphere and is essential to understand hydrological processes (Entin et al., 2000). Crop water requirements vary in time and space due to climate, management, phenological stage of the crop, and cultivar, then, their assessment must be local (Doorenbos and Pruitt, 1977). Assuring an adequate soil water content in the root zone during critical periods is needed for obtaining optimum yields.
Nowadays, different methods for determining soil water content are available. Among them, Frequency Domain Reflectometry (FDR) is widely used (Vera et al., 2009).

Therefore, the aim of this study was to quantify the soil moisture dynamics in the root-influenced zone and to estimate the daily water consumption by maize using FDR. Data from this device were compared to crop evapotranspiration assessed by the Penman Monteith equation (Allen et al., 1998).

\section{Materials and methods}

\subsection{Description of the study site}

The experiment was conducted in a maize (Zea mays, L.) field at the "Centro de Investigaciones Agrarias de Mabegondo" (CIAM), in Coruña (Spain) $\left(43^{\circ} 14^{\prime} \mathrm{N}, 8^{\circ} 15^{\prime} \mathrm{W}\right.$, $98 \mathrm{~m}$ a.s.l.) during the agricultural years of 2008 and 2009 (from June to October). The soil at the study site was classified as a Cambisol (FAO-ISRIC, 1998). The basic soil properties are given in Table 1.

The climate is temperate with mild and rainy winters and relatively dry summers. The yearly average rainfall at this site is $1128 \mathrm{~mm}$ and the average temperature is $13.3^{\circ} \mathrm{C}$ (Báez et al., 2005). The study period comprises the growing sessions of 2008 and 2009, namely, from June to October each year. The total rainfall for these periods was $490.4 \mathrm{~mm}$ and $365.7 \mathrm{~mm}$ in 2008 and 2009, respectively. During the two growing seasons considered, the average temperature ranged between 9.3 and $18.2^{\circ} \mathrm{C}$.

During the study period, the maize crop was subjected to conventional agricultural practices, which included no irrigation. A weekly evaluation of the phenological stage of the crop was performed.

\subsection{Estimation of potential and crop evapotranspiration}

Climatic data from a station located in the study site were used to calculate the reference evapotranspiration $\left(\mathrm{ET}_{0}\right)$, at a daily basis, using the Penman-Monteith equation (Allen et al., 1998): 
$\mathrm{ET}_{0}=\frac{0.408 \Delta\left(R_{\mathrm{n}}-G\right)+\gamma \frac{900}{T+273} u_{2}\left(e_{\mathrm{s}}-e_{\mathrm{a}}\right)}{\Delta+\gamma\left(1+0.34 u_{2}\right)}$

where $\mathrm{ET}_{0}$ is the reference evapotranspiration $\left(\mathrm{mm} \mathrm{day}^{-1}\right)$, $R_{\mathrm{n}}$ is the net radiation at the surface $\left(\mathrm{MJ} \mathrm{m}^{-2} \mathrm{day}^{-1}\right), G$ is the ground heat flux density $\left(\mathrm{MJ} \mathrm{m}^{-2} \mathrm{day}^{-1}\right), T$ is the mean daily air temperature at $2 \mathrm{~m}$ height $\left({ }^{\circ} \mathrm{C}\right), u_{2}$ is the wind speed at $2 \mathrm{~m}$ height $\left(\mathrm{m} \mathrm{s}^{-1}\right), e_{\mathrm{s}}$ is the saturation vapour pressure $(\mathrm{kPa}), e_{\mathrm{a}}$ is the actual vapour pressure $(\mathrm{kPa}), \Delta$ is the slope of the saturation vapour pressure curve $\left(\mathrm{kPa}^{\circ} \mathrm{C}^{-1}\right)$, and $\gamma$ is the psychrometric constant $\left(\mathrm{kPa}^{\circ} \mathrm{C}^{-1}\right)$.

Crop evapotranspiration $\left(\mathrm{ET}_{\mathrm{c}}\right)$ was calculated by multiplying $\mathrm{ET}_{0}$ and a crop coefficient $\left(K_{\mathrm{c}}\right)$ for maize. This crop coefficient depends on the phenological stage of maize. We worked with "yield maize" and the final stage of crop development was very short (around 15 days), therefore, in our case, three phenological stages were considered: initial, middle and final (Table 2). Their corresponding $K_{\mathrm{c}}$ values were 0.3, 1.2, and 1.0, respectively (Allen et al., 1998).

\subsection{Soil water content measurements}

The volumetric soil water content was monitored continuously by a multi-depth capacitance probe (EnviroSCAN SOLO, Sentek, Australia). These measurements are based on frequency domain reflectometry (FDR) yielded by a series of coil capacitor circuits. Mid-points of the sensors were sited at 20,40 and $60 \mathrm{~cm}$ depth and connected to a datalogger which stored an average value every hour. The probe was installed in a representative location within the plot. The spot within the plot where the probe was installed was selected after a previous study in the same area using a non-continuous measuring probe in several locations within the plot (MestasValero et al., 2009).

Each sensor inside the PVC access tube was previously normalized taking readings exposed to air and water before being installed in the field following the manufacturer's guidelines. The accuracy of the data obtained by this equipment depends on the installation procedure since the radius of influence of the sensors' electric field is relatively small (Evett et al., 2002). In the absence of air gaps between sensor and soil, its precision can be as good as $\pm 0.01 \mathrm{~m}^{3} \mathrm{~m}^{-3}$ (Muñoz-Carpena, 2004).

A total of 46 days were surveyed per year, between 29 June and 4 October in 2008 and between 16 June and 13 September in 2009. On those days, slight or no rainfall was observed; therefore, water loss from soils was considered to be consumed by maize, although it included evaporation from the soil, drainage and uptake of water by the crop.

To estimate the soil water balance, we used the method described by Arauzo et al. (2003). For each period between two rainfalls, we calculated the evapotranspiration and drainage, and also the variation in soil water content. Soil water balance is commonly represented as $\Delta S=I+R-D-\mathrm{ET}_{\mathrm{c}}$, where $\Delta S$ is the variation in soil water content, $I$ is irrigation,
Table 2. Crop developmental stages for both years. Note: $K_{\mathrm{c}}$ denotes crop coefficient.

\begin{tabular}{|c|c|c|c|}
\hline \multirow{2}{*}{$\begin{array}{l}2008 \\
\text { Planting date: } 24 \text { June }\end{array}$} & \multicolumn{3}{|c|}{ Crop development stages } \\
\hline & Initial & Middle & Final \\
\hline Period length (days) & 35 & 47 & 14 \\
\hline$K_{\mathrm{c}}$ & 0.3 & 1.2 & 1 \\
\hline 2009 & \multicolumn{3}{|c|}{ Crop development stage } \\
\hline Planting date: 21 June & Initial & Middle & Final \\
\hline Period length & 32 & 54 & 18 \\
\hline$K_{\mathrm{c}}$ & 0.3 & 1.2 & 1 \\
\hline
\end{tabular}

$R$ is rainfall, $D$ is drainage, and $\mathrm{ET}_{\mathrm{c}}$ is crop evapotranspiration (Vera et al., 2009). In our case, since the maize was not irrigated and we only used data from days with no rainfall, soil water balance was simplified to $\Delta S=D+\mathrm{ET}_{\mathrm{c}}$. Furthermore, we considered drainage as negligible and variations in soil water content were accounted for as crop water uptake. $\Delta S$ values were calculated as the difference in the soil water content between two consecutive days.

\subsection{Data analysis}

Crop evapotranspiration $\left(\mathrm{ET}_{\mathrm{c}}\right)$ values were compared to those of soil water content and water consumption by the crop determined by FDR using regression analysis. Data were analysed using R software version 2.12.1 (R Development Core Team, 2010).

\section{Results}

Maize growing dynamics followed a sigmoidal curve due to different growing rates during its development cycle. The maximum development was observed at 50 days after sowing, approximately until the end of blooming and beginning of grain formation. After these periods, the growth rate was negligible. Knowledge of the different phenological stages and crop growing processes may help to determine crop water requirements and avoid water stress during critical phases that may considerably affect the quantity and quality of the final yield.

The average daily $\mathrm{ET}_{0}$ was $4.16 \mathrm{~mm} \mathrm{day}^{-1}$ in 2008 and $4.64 \mathrm{~mm} \mathrm{day}^{-1}$ in 2009. These values ranged between 2 and $6.5 \mathrm{~mm} \mathrm{day}^{-1}$ in both years studied (Fig. 1). The crop water uptake was mainly produced during the day and, significantly, from $12 \mathrm{~h}$. The highest values were observed between 15 and $17 \mathrm{~h}$. In contrast, this water uptake at night or at dawn was low. These observations are in accordance with the daily dynamics of water content in the soil profile (Fig. 2), when a greater decrease of water content is produced from noon in 

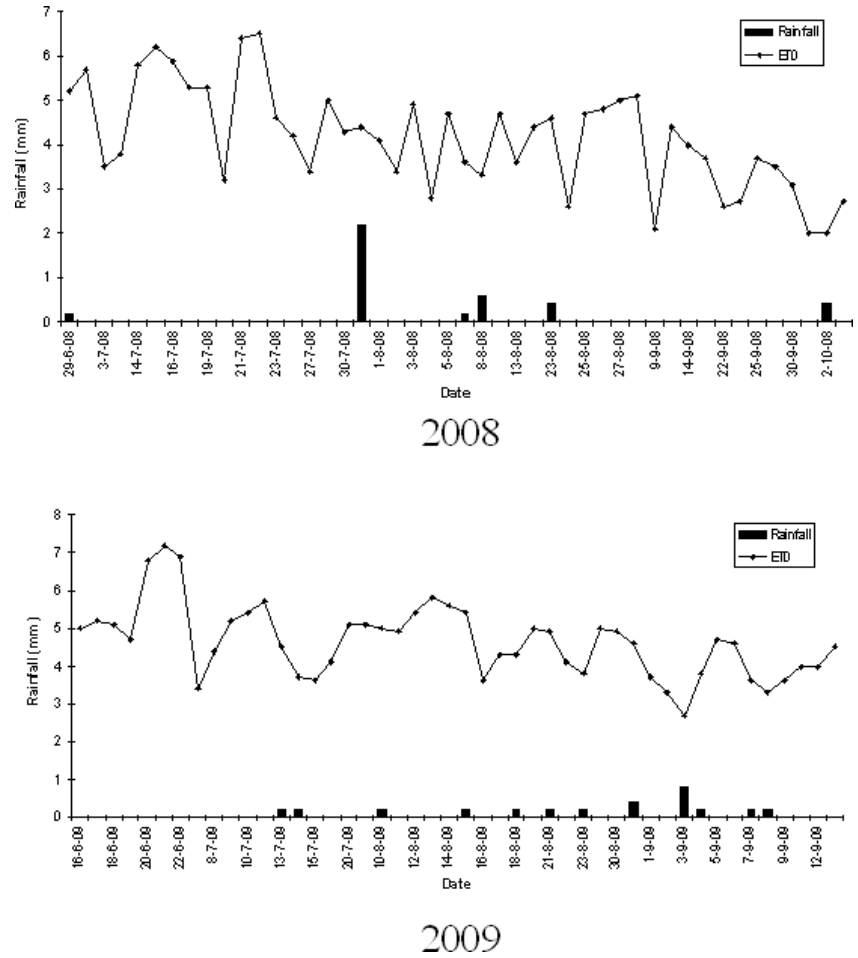

Fig. 1. Rainfall and daily potential evapotranspiration estimated during the two study periods.

both years studied. This decreasing is rapid till $18 \mathrm{~h}$, approximately, and then it reduces its velocity.

The magnitude of the diurnal soil water loss was more evident in the first layer $(0-20 \mathrm{~cm}$ depth) and less important in the subsequent soil layers (Table 3 ). In fact, water consumption in the first soil layer was almost 4 times greater than that in the deepest range considered $(40-60 \mathrm{~cm}$ depth) for both years studied. Water loss from the top horizon included evaporation losses.

During daytime and in absence of rainfall or any other water supply, soil water content varies (Fig. 2) due to the bioclimatic demand of the crop $\left(\mathrm{ET}_{\mathrm{c}}\right)$. This soil water loss progressively diminishes from one day to the following due to the progressive consumption by the crop of available water.

Daily $\mathrm{ET}_{\mathrm{c}}$ values and crop water consumption were significantly correlated (Fig. 3). A potential relation was observed with regression values of 0.56 and 0.54 for 2008 and 2009, respectively. Although significant, these regressions do not explain data spread. However, $\mathrm{ET}_{\mathrm{c}}$ was always greater than crop water consumption determined by FDR. Similar relations were observed between evapotranspiration and soil water content (data not shown).
Table 3. Daily average crop water consumption $\left(\mathrm{mm} \mathrm{day}^{-1}\right)$ and soil water content ( $\%$ ) for each analyzed soil layer during the two years studied.

\begin{tabular}{lrrrr}
\hline & \multicolumn{4}{c}{ Depth (cm) } \\
\cline { 2 - 5 } & $0-60$ & $0-20$ & $20-40$ & $40-60$ \\
\hline 2008 & & & & \\
\hline Crop water consumption & 2.13 & 1.13 & 0.58 & 0.42 \\
Soil water content & 23.12 & 18.72 & 22.98 & 24.36 \\
\hline 2009 & & & & \\
\hline Crop water consumption & 2.95 & 1.88 & 0.67 & 0.40 \\
Soil water content & 25.59 & 22.32 & 23.68 & 30.78 \\
\hline
\end{tabular}

\section{Discussion}

In the humid zone of Spain, climate change may increase the water requirements of crops as suggested by Moratiel et al. (2011) for other regions in Spain. In this context, the use of a methodology that accurately estimates crop water consumption is of paramount importance in order to make a wise use of water resources. In this study, we observed that estimating $\mathrm{ET}_{\mathrm{c}}$ using the Penman-Monteith approach overestimates crop water requirements in the case of maize, whereas FDR provided a more accurate prediction. This may be due to a lack of adjustment of the $K_{\mathrm{c}}$ values for our study area; therefore, it may indicate that measuring soil water content is preferable to relying on models from meteorological data.

However, decreases in soil water content may be due to crop evapotranspiration, drainage, and moisture redistribution within the soil profile. Our results showed that crop evapotranspiration was mainly produced during the day. In contrast, $\mathrm{ET}_{\mathrm{c}}$ values at night or at dawn were low. Therefore, water loss in the soil profile at night and dawn was considered to be caused by drainage, as we observed a certain decline in soil water content during this time of the day.

However, as also reported by Vera et al. (2009), the FDR probes explore a small soil volume and, for agricultural purposes, several probes should be installed in the field to achieve a high representativeness of the culture water requirements. For instance, the fact that most of the soil water loss was produced in the shallowest soil layer indicates the high root concentration in this first layer, which may also prove the potential use of these sensors as a biological indicator.

In conclusion, FDR probes are useful for calculating crop water consumption and estimating the evolution through time of soil water content, being accurate in assessing crop water requirements. Furthermore, they would be useful in the assessment of saturation risks or water stress (drought), thus aiding in the decision making, for instance, in irrigation management. Results from this study can be used for crop water 

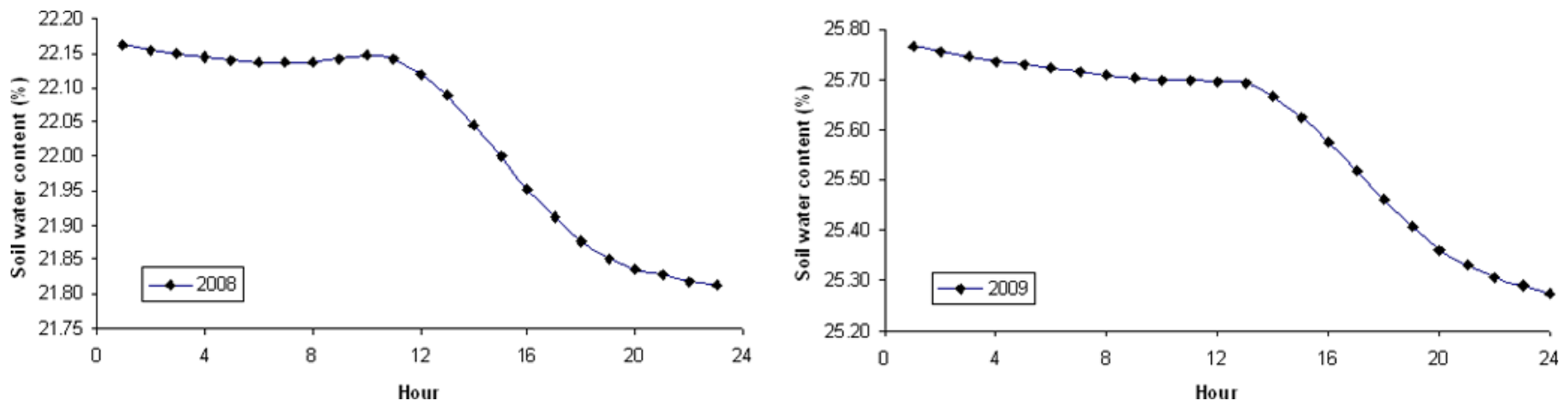

Fig. 2. Hourly evolution of soil water content in the root zone $(0-60 \mathrm{~cm}$ depth). Data are averaged from the analyzed days, namely 46 days in 2008 and 2009.
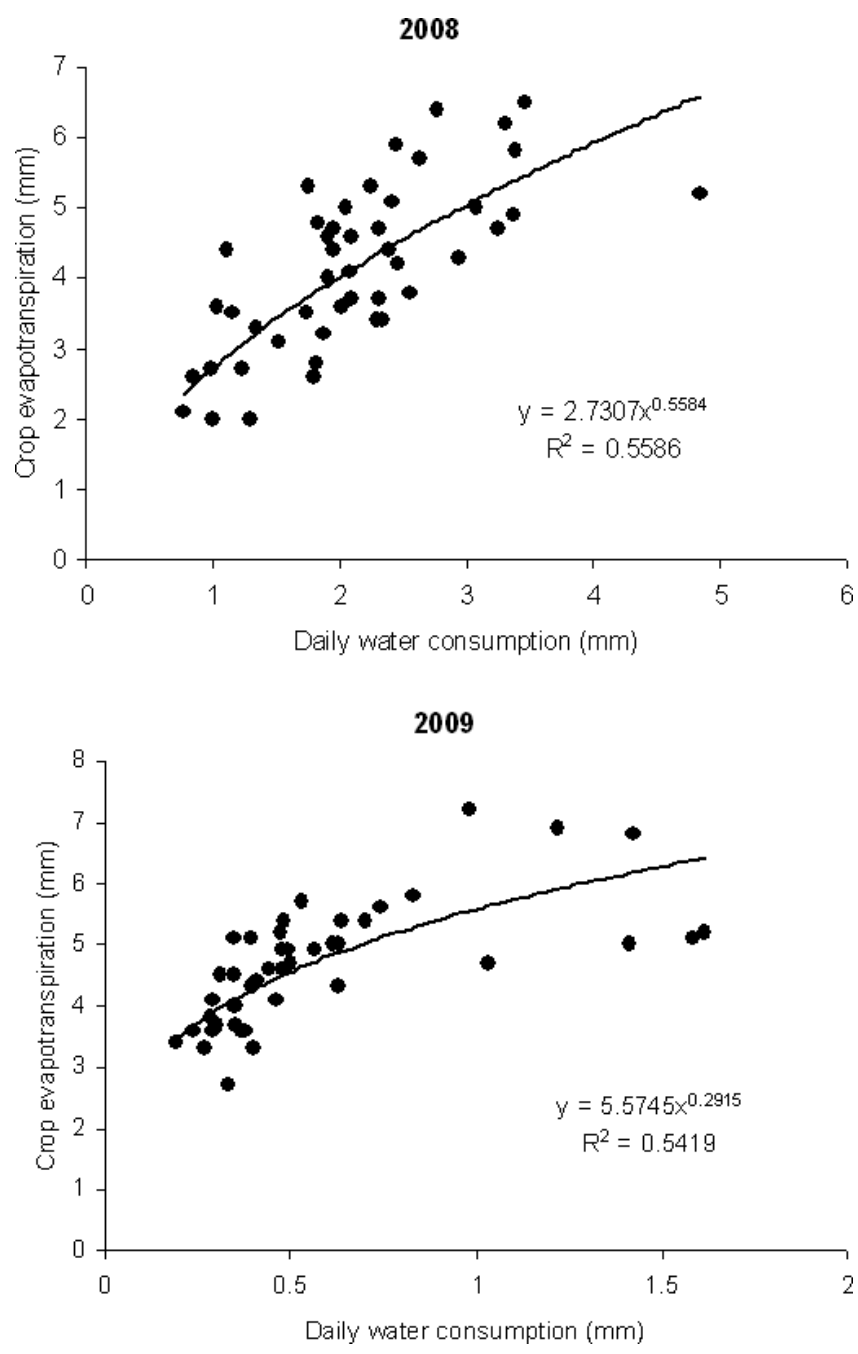

Fig. 3. Relation between daily crop evapotranspiration $\left(\mathrm{ET}_{\mathrm{c}}\right)$ and daily crop water consumption determined by FDR during the two years studied: 2008 and 2009. requirement modelling purposes employing such models as ISAREG (Pereira et al., 2003), which has been successfully applied to maize crops in Galicia (Cancela et al., 2006) and may help to improve irrigation practices in humid zones.

\section{Conclusions}

Monitoring water content within the soil profile (each $10 \mathrm{~cm}$ depth) and with a high data acquisition frequency (every hour) allowed us to estimate the real evapotranspiration of maize crop. Measuring soil water content within the rooting zone $(0-60 \mathrm{~cm}$ depth) revealed the dynamics of soil moisture due to root water uptake. This information is valuable for irrigation purposes. In addition, the estimation of crop water uptake by FDR was more accurate than the use of the FAO Penman-Monteith equation, which overestimates crop water requirements.

Acknowledgements. This work was funded in part by Spanish Ministry of Science and Innovation (MICINN) within the framework of the project reference CGL2009-13700-C02. Roger M. Mestas-Valero was supported by the Programme AlBan, the European Union Programme of High Level Scholarships for Latin America, scholarship no. E07D403924PE. José Manuel Mirás Avalos thanks Xunta de Galicia for funding his contract within the framework of the program "Isidro Parga Pondal". Useful comments from two reviewers are gratefully acknowledged.

Edited by: A. M. Tarquis

Reviewed by: two anonymous referees 


\section{References}

Aaron, M., Beutler, B. S., and Keller, A.: Implementation of FAO56 Penman-Monteith evapotranspiration in a large scale irrigation scheduling, Water and Environmental Resources Congress, Alaska, 1996.

Allen, R. G., Pereira, L. S., Raes, D., and Smith, M.: Crops evapotranspiration, Guidelines for computing crop requirements, Irrigations and Drainage Paper 56, FAO, Rome, 300 pp., 1998.

Alsamamra, H., Ruiz-Arias, J. A., Pozo-Vázquez, D., and TovarPescador, J.: A comparative study of ordinary and residual kriging techniques for mapping global solar radiation over southern Spain, Agr. Forest Meteorol., 149, 1343-1357, 2009.

Arauzo, M., Díez, J. A., and Hernáiz, P.: Estimación de balances hídricos y lixiviación de nitratos en sistemas agrícolas, in: Investigación de la Zona no Saturada, vol. VI, ZNS'03, edited by: Álvarez-Benedí, J., and Marinero, P., Instituto Tecnológico Agrario de Castilla y León, Universidad Europea Miguel de Cervantes, Valladolid, Spain, 39-44, 2003.

Báez, D., Castro, J., López, J., and Novoa, R.: Efecto del manejo de praderas dentro de una explotación de ganado vacuno en la evolución de nutrientes en el suelo durante el periodo de drenaje, in: Investigación de la Zona no Saturada, Vol. VII, ZNS'05, edited by: Samper, J. and Paz González, A., Universidade da Coruña, A Coruña, Spain, 57-62, 2005.

Cancela, J. J., Cuesta, T. S., Neira, X. X., and Pereira, L. S.: Modelling for improved irrigation water management in a temperate region of Northern Spain, Biosyst. Eng., 94, 151-163, 2006.

Doorenbos, I. and Pruitt, W. O.: Crop water requirements, FAO Paper 24, Rome, Italy, 144 pp., 1977.

D’Urso, G. and Menenti, M.: Mapping crop coefficients in irrigated areas from Landsat TM images, Proceed, Opt. Eng., 2585, 4147, 1995.

Entin, J. K., Robock, A., Vinnikov, K. Y., Hollinger, S. E., Liu, S., and Namkhai, A.: Temporal and spatial scales of observed soil moisture variations in the extratopics, J. Geophys. Res., 105, 11865-11877, 2000.

Evett, S. R., Ruthardt, B., Kottkamp, S., Howell, T., Scheneider, A., and Tolk, J.: Accuracy and precision of soil water measurements by neutron, capacitance and TDR methods, in: Proceedings of the 17th Water Conservation Soil Society Symposium, Thailand, 2002.

FAO-ISRIC: World Reference Base for Soil Resources, World Soil Resources Reports 84, FAO, Rome, Italy, 1998.

Goldhammer, D. A., Fereres, E., Mata, M., Girona, J., and Cohen, M.: Sensitivity of continuous and discrete plant and soil water status monitoring in peach trees subjected to deficit irrigation, J. Amer. Soc. Hortic. Sci., 124, 437-444, 1999.

IPCC: Summary for Policymakers, in: Climate Change 2007: The Physical Science Basis, Contribution of Working Group I to the Fourth Assessment Report of the Intergovernmental Panel on Climate Change, edited by: Solomon, S., Qin, D., Manning, M., Chen, Z., Marquis, M., Averyt, K. B., Tignor, M. and Miller, H. L., Cambridge University Press, Cambridge, United Kingdom and New York, NY, USA, 2007.
Mestas Valero, R. M., García, M. I., Báez, M. D., and Paz González, A.: Estimación del consumo de agua en el cultivo del maíz, mediante el seguimiento de humedad en la zona radicular con sondas de capacitancia (FDR), in: Estudios en la Zona no Saturada del Suelo vol. IX, edited by: Silva Rojas, O. and Carrera Ramírez, J., CIMNE, Barcelona, Spain, 83-88, 2009.

Mirás-Avalos, J. M., Mestas-Valero, R. M., Sande-Fouz, P., and Paz-González, A.: Consistency analysis of pluviometric information in Galicia (NW Spain), Atmos. Res., 94, 629-640, 2009.

Moratiel, R., Snyder, R. L., Durn, J. M., and Tarquis, A. M.: Trends in climatic variables and future reference evapotranspiration in Duero Valley (Spain), Nat. Hazards Earth Syst. Sci., 11, 17951805, doi:10.5194/nhess-11-1795-2011, 2011.

Mounzer, O. H., Mendoza-Hernández, J. R., Abrisqueta-Villena, I., Tapia-Vargas, L. M., Abrisqueta-García, J. M., Vera-Muñoz, J., and Ruiz-Sánchez, M. C.: Soil water content measured by FDR probes and thresholds for drip irrigation management in peach trees, Agricultura Técnica en México, 34, 313-322, 2008.

Muñoz-Carpena, R.: Field devices for monitoring soil water content, University of Florida, Bulletin 343, 2004.

Neira, X. and Paz, A.: Water balance in irrigated maize plots, Trans. 15th World Congress of Soil Science, Acapulco, Mexico, 2b, 5657, 1994.

Papadavid, G. C., Agapiou, A., Michaelides, S., and Hadjimitsis, D. G.: Brief communication "The integration of remote sensing and meteorological data for monitoring irrigation demand in Cyprus", Nat. Hazards Earth Syst. Sci., 9, 2009-2014, doi:10.5194/nhess-9-2009-2009, 2009.

Paz, A., Neira, A., and Castelao, A.: Soil water regime under pasture in the humid zone of Spain: validation of an empirical model and prediction of irrigation requirements, Agric. Water Manage., 29, 147-161, 1996.

Pereira, L. S., Teodoro, P. R., Rodríguez, P. N., and Teixeira, J. L.: Irrigation scheduling simulation: the model ISAREG, in: Tools for drought mitigation in Mediterranean Regions, edited by: Rossi, G., Cancelliere, A., Pereira, L. S., Oweis, T., Hatanawi, M., and Zairi, A., Kluwer, Dordrecht, The Netherlands, 161180, 2003.

R Development Core Team: R: A language and environment for statistical computing, R Foundation for Statistical Computing, Vienna, Austria, ISBN 3-900051-07-0, available at: http://www. R-project.org/, 2010.

Vera, J., Mounzer, O., Ruiz-Sánchez, M. C., Abrisqueta, I., Tapia, L. M., and Abrisqueta, J. M.: Soil water balance trial involving capacitance and neutron probe measurements, Agr. Water Manage., 96, 905-911, 2009.

Zhang, X., Chen, S., Sun, H., Shao, L., and Wang, Y.: Changes in evapotranspiration over irrigated winter wheat and maize in North China Plain over three decades, Agr. Water Manage., 98, 1097-1104, 2011. 